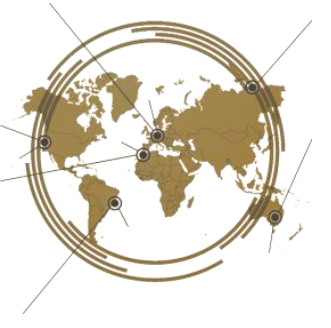

\title{
Enacting an emergency EFL course in an Indonesian disadvantaged condition
}

\author{
Khusnul Khotimah ${ }^{*}{ }^{1}$ Kurniawan Apgrianto, ${ }^{1}$ Mutmainnah Mustofa ${ }^{2}$ \\ M. Faruq Ubaidillah, ${ }^{3}$ Shinta Amalia ${ }^{3}$ \\ ${ }^{1}$ English Department, Universitas Mataram, Indonesia, ${ }^{2}$ Department of English Education, Universitas Islam Malang, \\ Indonesia, ${ }^{3}$ Center for Scientific Publication, Universitas Negeri Malang, Indonesia
}

Situated in a disadvantaged condition in Lombok, Indonesia, the present study looks at the enactment of an emergency EFL course after earthquake and aftershock circumstances in a public university in the region. For such a purpose, forty-two non-English department students who attended the course in four face-to-face and nine asynchronous meetings were recruited using a convenience sampling technique. A set of questionnaire was disseminated to document participants' responses on the course implementation. Observation and semi-structured interviews were also conducted to portray the pedagogical praxis. The findings suggest that the course delivery did not utterly reflect an effective teaching-learning process accordingly due to various factors. Barriers to using the WhatsApp tool also existed. Interestingly, the students positively reflected the course as the best way to learn in a disadvantaged condition. However, they were not confident with their attainment in English skills and components. Further considerations on how to design materials and assessment instruments and build a decent interaction are needed in learning under such disadvantaged condition.

Keywords: aftershock, earthquake, EFL course, teaching-learning process

OPEN ACCESS

ISSN 25033492 (online)

${ }^{*}$ Correspondence:

Khusnul Khotimah

khusnul_pena@unram.ac.id

Received: 4th May 2021 Accepted: 12th October 2021 Published: 14th October 2021

Citation: Khotimah, K. Apgrianto, K. Mustofa,

M. Ubaidillah, M.F. \& Amalia, S. (2021). Enacting an emergency EFL course in an Indonesian disadvantaged condition.

J. Eng. Educ. Society. 6:2.

doi:10.21070/jees.v6i2.1384

\section{INTRODUCTION}

"Dear my lovely students, it is not easy to learn in a disadvantaged condition, but giving up doesn't help anything. Earthquakes may destroy our homes and belongings, but they may not destroy our courage and passion for learning." A quote from the classroom teacher.

The above-quote is illustrative of a classroom condition based in Lombok, Indonesia, which was hit by a devastating earthquake in 2018. Inspired by such a disadvantaged condition, the present study was designed to uncover teaching-learning enactment, particularly in the EFL course, and students' responses to it. We identified that research investigating the impacts of natural disasters on teaching-learning has not received ample attention from researchers (Pietro, 2015). With this in mind, this study aims at revealing how teaching-learning is enacted and to what extent the students respond to the practice.

The earthquake which occurred in Lombok on July 29, 2018, with a 6.4 magnitudes followed by thousands of devastating infrastructure, including a 7.0 magnitude aftershock on August 5, 2018 destroyed thousands of houses and buildings. Refugees were in a horrendous trauma and then started building tents at the open spaces to avoid sudden aftershocks (Baharun, personal communication, January 17, 2019). Economic sectors and legal services were hampered. Teaching and learning processes in schools and universities were halted unavoidably for a month. In this condition, the English as a foreign language (EFL) course in universities was enacted using online platforms. 
Specifically, the students who enrolled in the EFL course in the gap semester were in a traumatic condition. Two out of forty-two students lost their houses, whereas the rest of them could not live at their own houses due to the house's severe damages and the fear of the frequent aftershocks. The only thing they could do was staying in the tents or refugee camp with their families; they could not even go to the class.

Alike with the students' condition, university buildings were severely damaged and could not be used to facilitate the teaching-learning process. The university was still hushed, with no lecturers, staff, and students. Moreover, the regular aftershocks made the situation frightening to sit or walk around as well as to conduct academic purposes. Within these disadvantaged circumstances, the English lectures were encouraged to design an online learning platform to accomplish the course in one semester. The lecturers, along with the students' agreement and commitment, set out an asynchronous online teachinglearning using WhatsApp.

This study sought to investigate the course enactment and the students' reflection upon learning using such a tool. Empirical studies depict that the impact of natural disasters in educational sectors is not exclusively studied. Several scholars attempted to explore such an issue using different perspectives, such as the integration of disaster management into the curriculum (Seyle, Widyatmoko, \& Silver, 2013), the importance of student-teacher relationship to improve students' emotional stability after disaster trauma (Moore, 1989), the role of teachers in a recovery phase (Mutch, 2015), and the academic impact of a natural disaster (Pietro, 2015). However, studies picturing the teaching-learning process after the earthquake and in the wake of aftershocks are underexplored.

It is undeniable that conducting the teaching-learning process in such a condition cannot be considered similar to a normal situation. Previously in Italy, Pietro (2015) found that the L'Aquila earthquake affected not only the learning environment and psychological factors but also had tremendous impacts in the area of academic performance for both teachers and students. In his study, the L'Aquila earthquake decreased the students' opportunity to graduate on time.

The use of technologies offers promising benefits. It provides flexibility in many platforms of complexity, such as time and place (Song et al., 2013). Teachers, instructors, students, and school stakeholders are privileged with some adoptions at their convenience, although they may feel reluctant to perform online learning at the beginning of their classroom activities (Redmond, 2011).

The deployment of technology in the education sectors has been studied several decades ago, for example, initiated by Coldeway (1995). He highlighted four approaches in using technology, such as same time-same place, different time-same place, same time-different place, and different place-different time. On the other hand, other scholars prefer to use two significant terms such as synchronous learning (for same time-same place and same time-different place teaching-learning) and asynchronous learning (for different time-same place and different place-different time teachinglearning) (see Chen, Ko, Kinshuk, \& Lin, 2005; Giesbers, Rienties, Tempelaar, \& Gijselaers, 2014; Johnson, 2006; Offir, Lev, \& Bezalel, 2008).

In line with these different perspectives, Redmond (2011) further compared and contrasted synchronous and asynchronous learning processes. He suggested that teachers consider the details of those two processes before deciding to use one of them. At this point, schools or university stakeholders, particularly teachers, have the authority to choose a suitable approach considering the most applicable, possible, effective approach to teaching enactment. Therefore, using certain technological tools can be an alternative to conduct a teaching-learning process after the earthquake and aftershocks. In this study, the discussion focused on asynchronous learning using WhatsApp in the EFL course enacted in one public university in Indonesia as an emergency choice after the earthquake and aftershocks.

In relation to such a condition, previous studies have been conducted to examine the impact of WhatsApp use in EFL classes. Many of the findings found that it gave positive effects on students' achievement and attitudes in learning (Amry, 2014; Arifani, 2019; Zulkanain, Miskon, \& Abdullah, 2020), vocabulary enhancement (Awada; 2016; Bensalem, 2018; Hani, 2014; Man, 2014), and reading and writing skills (Maria, 2016).

However, Hamad (2017), despite revealing some benefits of using WhatsApp, listed some considerations for teachers such to (1) have more time and experiences to prepare the materials, (2) to be more cautious in classroom management, (3) to monitor students' learning process as well as the originality of students' work, while students are also encouraged to participate actively in the WhatsApp discussion. On a broader scope, Chauhan (2017) described the advantages and disadvantages of asynchronous learning using technology properties, as stated in the following Table 1 .

TABLE 1 Chauhan's (2017) descriptions of advantages and disadvantages of asynchronous learning

\begin{tabular}{ll}
\hline \multicolumn{1}{c}{ Advantages } & Disadvantages \\
- Offers students to be & - Lacks instant feedback \\
more independent in & - Lacks personal interaction \\
controlling their learning & - No live collaboration and \\
- Gives time to reflect & real-time activities \\
- Offers flexibility & - Can cause a lack of \\
- Reduces social obstacles & motivation and lead to \\
- Interactive, regardless of & procrastination \\
location and time & - Requires self-discipline \\
barriers &
\end{tabular}

Another essential aspect of online learning application in teaching is the managerial system. Using an application such as WhatsApp is not limited as to how to use it as a repository tool only in which the teachers can store and distribute the material more easily. The teachers as decision-makers should also consider another factor, just as using the internet application in WhatsApp for managing the teaching- 
learning process, supporting online group work, and giving students opportunities to do project-based learning.

In other words, teachers are required to be able to establish an effective interaction in the WhatsApp group. In line with this suggestion, Neroni et al. (2019) also argued that interaction determines the satisfaction or dissatisfaction of distance-learning. Thus, establishing an interaction is a vital component in the teaching-learning process. Earlier, Moore (1989) categorized the interaction in an instruction into three types, such as learner-teacher interaction, learnercontent interaction, and learner-learner interaction. More sophisticatedly, Redmond (2011) suggested four types of interaction based on his research findings, these are, learnerteacher interaction, learner initiating interaction with a teacher, teacher facilitating learner-to-learner interaction, and learner initiating learner-to-learner interaction.

Another exploration of classroom interaction using online learning platforms was also carried out to reveal what type of interaction that contributes to students' learning attainment (see Huang et al., 2019). In their study, teacherstudent interaction had a positive impact on students' achievement, although student-student interaction did not run well. Unfortunately, research investigating interaction using WhatsApp learning enactment, particularly in Indonesian education sectors with a disadvantaged condition, seems sparse. To fill such a void, the present study was carried out to explore the extent to which the implementation of an emergency EFL course facilitates active learning and interaction as viewed from students' reflections and learning documents.

The results are expected to shed light on considerations as to how teacher and teacher educators design learning enactment, including materials and assessment, in a disadvantaged condition. Given that this issue is underexposed, further research is expected to investigate the teaching-learning process using multilayered perspectives.

\section{METHODS}

This study was carried out within a three-week emergency condition at one public university in Lombok, Indonesia. A case study with multiple data gathering methods was used as the appropriate design to capture learning discourses situated in one English language class at the university. Forty-two freshmen (henceforth, participants) were recruited through a convenience sampling technique. They were all from nonEnglish departments at the university. The data were obtained from a self-made questionnaire, semi-structured interviews, and observation.

The questionnaire was distributed to the participants through the WhatsApp group in which they were asked to respond to it and asked to hand it in on the same day they submitted the portfolio. At the following step, when submitting the portfolio and questionnaire, the students were interviewed in a face-to-face setting. Each interview lasted between 30 to 45 minutes.

The interview session was set in an informal situation in the form of reflection on the instructions. This interview intended to capture students' reflection and appraisal upon the learning activities in the WhatsApp group. This setting was aimed at creating a more natural situation in which the students did not realize that they were being interviewed. No specified number of students was targeted to be in the interview. Particularly, when the same pattern of response was found, the interview was stopped. In this case, at the ninth student, sufficient data were found. Besides, the observation was also done within a three-week learning process in the face-to-face classroom.

Data from the questionnaire and observation were triangulated and compared with the interview transcripts. We attempted to document emerging themes from questionnaire, observation, and interview. To capture such themes, we carefully compared each data and sought for similar lines of issues. Subsequently, the data were also related to previous studies and theories in order to appropriately construct the themes.

\section{RESULTS AND DISCUSSION}

Findings from the study are detailed into four emerging themes: the approach in teaching-learning enactment, teaching materials, teachers and students' classroom interactions, and assessment process.

\section{The Approach in Teaching-Learning Enactment}

The approach employed in this course was an asynchronous teaching-learning process conducted from different places and at different times. In this case, the teacher and students communicated using the WhatsApp group. The teacher decided to use this approach after doing a brief observation resulting in some considerations such as 1) students' residence distance, 2) disadvantaged condition in Lombok, 3 ) the presence of a WhatsApp group covering all classroom members, 5) unpredictable earthquakes. Thereby, an asynchronous teaching-learning process using the WhatsApp group was deemed as the most possible and applicable approach to practice.

This teaching-learning process was different from the conventional classroom activities. In the previous course, each meeting had a series of steps starting from the opening, primary instruction, and closing. On the other hand, in this emergency course, nine-meeting instruction was seen as a continuum with a single opening in meeting 1 and a single closing in meeting 9. The detailed steps based on the documentary observation are synthesized as follows in Table $\underline{2}$. 
TABLE 2 | Course Arrangements

\begin{tabular}{|c|c|c|c|}
\hline Meeting and Date & Agenda & Details & Product \\
\hline \multirow[t]{4}{*}{ 1. August 14,2018} & $\begin{array}{l}\text { Opening from the } \\
\text { teacher }\end{array}$ & $\begin{array}{l}\text { The teacher described the manual and the detail of the teaching- } \\
\text { learning process }\end{array}$ & \\
\hline & Lesson 4 & The students independently learned the details in Unit 4 and then & Portfolio 1 \\
\hline & Travel and & responded to every question. The response should be written on a & \\
\hline & Adventure & piece of paper under the title Portfolio 1. & \\
\hline \multirow[t]{5}{*}{ 2. August 15,2018} & Lesson 5 & - The students independently learned the details in Unit 5 and & Portfolio 2 \\
\hline & Famous Place: & then responded to every question. & \\
\hline & Vanuatu & - The students found a resource explaining the concept of & \\
\hline & Singular and & Singular and Plural nouns and made some original & \\
\hline & $\begin{array}{l}\text { Plural nouns in } \\
\text { context }\end{array}$ & & \\
\hline \multirow[t]{4}{*}{ 3. August 16,2018} & Lesson 6 & - The students independently learned the details in Unit 6 and & Portfolio 3 \\
\hline & Unit 6: City Life & $\begin{array}{l}\text { then responded edto every question. } \\
\text { - The students found a resource explaining the concent of }\end{array}$ & \\
\hline & Present & Singular and Plural nouns and made some original & \\
\hline & $\begin{array}{l}\text { Continuous Tense } \\
\text { in context }\end{array}$ & examples. & \\
\hline 4. August 17,2018 & Quiz & The questions were integrated into the classroom activities & \\
\hline \multirow[t]{6}{*}{ 5. August 20,2018 } & Lesson 7 & - The students independently learned the details in Unit 6 & Portfolio 4 \\
\hline & Prehistoric & and then respond ed to every question. & \\
\hline & Timeline: & - The students found the resource explaining the concept of & \\
\hline & Dinosaurs & the preposition of time and place: at, in, on and made & \\
\hline & The use of & some original examples & \\
\hline & time: at, in, on. & & \\
\hline \multirow[t]{2}{*}{ 6. August 21, 2018} & Lesson 8 & - The students independently learned the details in Unit 8 & Portfolio 5 \\
\hline & A Penguin's Year & and then resnonded to every ouestion & \\
\hline \multirow[t]{6}{*}{ 7. August 24,2018} & Lesson 9 & - The students found additional reading text and retell the & Portfolio 6 \\
\hline & Additional & content. & \\
\hline & Reading text. & - The students distinguished the use of Simple Past Tense & \\
\hline & Simple Past & \& Present Perfect Tense. & \\
\hline & Tense\& Present & - The students provided some examples of them. & \\
\hline & Perfect Tense. & & \\
\hline 8. August 25,2018 & Review & $\begin{array}{l}\text { - The students learned unit } 4 \text { up to } 8 \text {. Any problem and } \\
\text { difficulty could be raised to the WhatsApp group to be } \\
\text { discussed. }\end{array}$ & Portfolio 7 \\
\hline 9. August 29,2018 & Closing & $\begin{array}{l}\text { - Final Exam items were uploaded on August 26, and the } \\
\text { students submitted them on August } 29 \text { before } 12 \text { o'clock. }\end{array}$ & Portfolio 8 \\
\hline
\end{tabular}

In this process of teaching-learning, the students were demanded to be more independent to learn the materials and find ample supporting resources. It is clearly seen from the table that the teacher and students were not set to do many discussions. In other words, WhatsApp was used as a repository rather than the space to discuss every single activity related to the lesson. The teacher attempted to be very effective in planning the course scene considering the inconvenient situation surrounding the university.

Out of the WhatsApp group, the students had to invest their time to read and understand the materials, made a summary of them, and answered related questions independently. Based on the questionnaire, the length of the learning can be seen from $\underline{\text { Chart } 1}$.

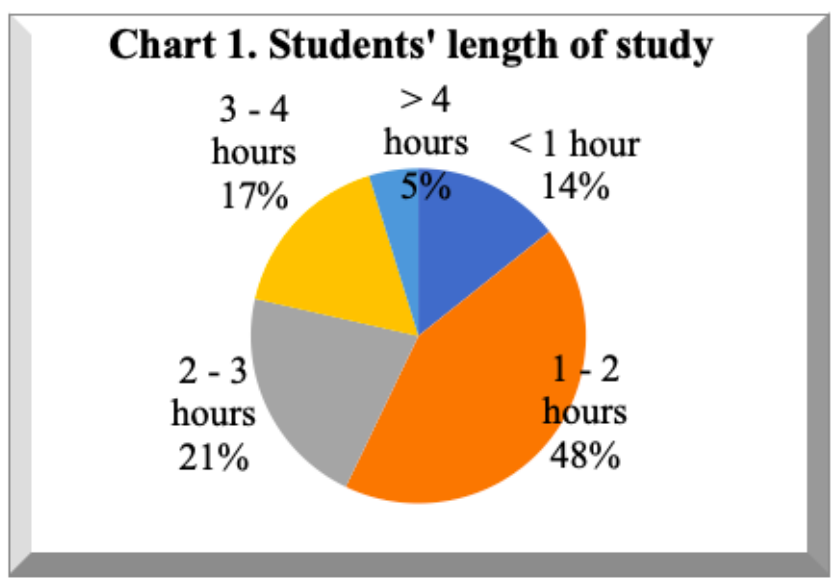

CHART 1 | Students' length of study 
The data also indicate that students $(48 \%)$ studied for about 1 up to 2 hours, and $14 \%$ of them studied less than an hour to accomplish one meeting's materials. This explains that many of them $(62 \%)$ appeared to not learn sufficiently.

\section{Teaching Materials}

Based on the teachers' document, the materials used in the course were mainly from the textbook provided. Besides, the teachers assigned students to find out specific grammatical structures from any sources. Different from the previous face-to-face meetings in which students were exposed to the four language skills; listening, speaking, writing, and reading, in this emergency course, students were only exposed to reading, writing materials, and some grammatical structures as the supplementary materials. Practically, sharing audios, videos, or some other sophisticated resources was not simple to manage due to some unforeseen and unavoidable factors such as lacking electricity and internet connection.

\section{Teachers and Students' Classroom Interactions}

Face-to-face meetings gave a chance for all class members to interact with one another. Teachers had a lot of access and opportunity to interact formally or informally with the students in the form of discussion, a short lecture, dialogue, private chat, and many other ways. Similarly, a wide range of interaction could happen among students in many activities, starting from the pair works, the group works, or on a broader scope. In this fashion, the students were also able to construct a small discussion either inside or outside the classroom to deal with their learning difficulties.

TABLE 3 | Offline interaction among students during the course

\begin{tabular}{lcccc}
\hline \multicolumn{1}{c}{$\begin{array}{c}\text { Number of } \\
\text { meeting }\end{array}$} & \multicolumn{4}{c}{ Topic of discussion } \\
& $\begin{array}{c}\text { Related to the learning } \\
\text { process }\end{array}$ & Related to the other things \\
& In number & In \% & In number & In \% \\
Once & 4 & 9.52 & 5 & 11.90 \\
Twice & 2 & 4.76 & 2 & 4.76 \\
3 times & 1 & 2.38 & 0 & 0 \\
4 times & 2 & 4.76 & 1 & 2.38 \\
\multicolumn{1}{r}{4} & 2 & 4.76 & 2 & 4.76 \\
$\quad$ times & & & & \\
Never & 19 & $(45.23 \%)$ & & \\
Noresponse & 2 & $(4.76 \%)$ & & \\
\hline
\end{tabular}

TABLE 4 | Online interaction among students during the course

\begin{tabular}{lcccc}
\hline \multicolumn{1}{c}{$\begin{array}{c}\text { Number of } \\
\text { meeting }\end{array}$} & \multicolumn{4}{c}{ Topic of discussion } \\
& $\begin{array}{c}\text { Related to the learning } \\
\text { process }\end{array}$ & Related to the other things \\
& In number & In \% & In number & In\% \\
Once & 5 & 11.90 & 2 & 4.76 \\
Twice & 2 & 4.76 & 2 & 4.76 \\
3 times & 2 & 4.76 & 2 & 4.76 \\
4 times & 4 & 9.52 & 3 & 7.14 \\
4 times & 0 & 0 & 2 & 4.76 \\
Never & 17 & $(40.47 \%)$ & \\
Noresponse & 1 & $(2.38 \%)$ & \\
\hline
\end{tabular}

Although Table 3 and Table 4 indicate the students' interaction frequency in a different setting, the data show a consistent pattern. A significant number of students (> 40\%) did not have verbal and physical contact with each other. Meanwhile, more than $5 \%$ of them met more than 4 times, and the rest of them met ranging from once up to three times. Considering the topic, few of the students interact with each other to discuss the lesson-related topic. The number of students discussing the lesson-related topic and the non-lesson-related topic is almost equal. These results indicate that, in general, the students did not do much interaction among them.

Table 5 illustrates the interaction type's frequency inside the WhatsApp group in which the conversation was mainly intended from students to teachers or vice versa $(86.89 \%)$. The student-student interaction occurred at no more than $10 \%$. In further investigation through the interview, it was found that students were more comfortable asking their accessible seniors (ones who did not belong to the class) rather than their classmates. This was due to a psychological factor. Almost all of the students stated that they were indifferent majors and had met each other only in four meetings, albeit they were not emotionally connected.

TABLE 5 | Interaction types' frequency in WhatsApp group

\begin{tabular}{lll}
\hline Interaction Types & Frequency & $\%$ \\
Teacher-student(s) & 643 & 86.89 \\
Student(s) - student(s) & 70 & 9.45 \\
Student(s)-student(s) initiated by the teacher & 8 & 1.08 \\
Others & 19 & 2.56 \\
\hline
\end{tabular}

\section{Assessment Process}

In the portfolio and final test submission day, based on the teacher's note, 3 out of 42 students (7.14\%) submitted the document late. Meanwhile, $7.14 \%$ was not a small number when there was much chance to do it on time. In this case, the teacher had plotted the time considering the required time and additional time. Besides, the application of this assessment process failed to promote a crucial process of conducting a practical assessment and giving feedback. This would give such ineffective learning conditions for the students since they did not have the opportunity to reflect on what they had learned in the instruction. In other words, the assessment in this course only served as the instrument to measure students' accomplishments (learning for assessment) and did not play the role of what so-called assessment for learning.

In particular, the application of the EFL emergency course after the earthquake and aftershocks in the university did not entirely reflect an effective instruction. The benefits of a particular technological tool use did not have a significant effect on what was promised. It might happen due to some unavoidable factors, such as insufficient time for the teachers to design a more comprehensible instruction, lack of electricity and internet connection, and some psychological factors. Therefore, some considerations on how to design more effective materials and assessment instruments and build a good interaction are needed in the learning. 
To investigate students' reflections of the course, a series of the questionnaire was distributed to the students via WhatsApp attachment. Moreover, when the students had to come to the university to finish administrative tasks such as signing the attendant list and the preparation for the new semester, a series of interview sessions was conducted to explore in-depth data about students' reflection. The data were analyzed and coded in two domains, such as 1) language skills and component enhancement and 2) advantages and disadvantages of the course. Table 6 presents data of language skills and component enhancement.

Based on Table 6, the students acknowledged that they mostly had some improvement in vocabulary, reading, and writing skills. Almost half of them also perceived improvement in grammatical structure. On the contrary, they did not positively feel improvement in terms of listening and speaking skills. The abovementioned result was deepened through an interview session. Furthermore, the result was seemingly congruent with what on the questionnaire result. The most common responses are 1) the course helped the students in finding the main ideas of a text faster, 2) the text in every unit exposed the students to be familiar with some new words, 3) the students practiced much in making sentences using specific grammatical structures, and 4) the students did not have the chance to do listening and speaking practice.

TABLE 6 | Students' reflection on their language skills and components

\begin{tabular}{rlll}
\hline \multicolumn{1}{c}{ Statement } & \multicolumn{2}{c}{$\begin{array}{c}\text { Number of Students } \\
\text { out of 42 }\end{array}$} \\
The course helps me to improve my: & \multicolumn{1}{c}{ In Number } & \multicolumn{1}{c}{ In \% } \\
1. & Listening skill & 0 & 0 \\
2. & Speaking skill & 5 & 11.90 \\
3. & Reading skill & 40 & 95.23 \\
4. & Writing skill & 27 & 64.28 \\
5. & Vocabulary & 42 & 100 \\
6. & Grammar & 18 & 42.85 \\
\hline
\end{tabular}

These findings are quite logical to be correlated with what the students were exposed to. Based on the materials description, the students were not intentionally exposed to listening and speaking related materials due to some inconvenient factors. However, based on the interview, most of the students were not confident about the result of their learning. They needed direct interaction with the teacher to get a more effective feedback. In response to this finding, some presuppositions could be seen as the factors underlying it. First, the students' English proficiency level could contribute to their dependency. Based on the data, this course was held for the students who obtained low scores from the previous semester. In other words, the students who participated in this course had a low level of English proficiency.

Understanding this condition, the teacher should be aware that the students with a low level of English proficiency needed more scaffold instruction and teacher's guidance, which both were not significantly facilitated in this kind of emergency course. Second, the quality and the quantity of the classroom interaction should be enhanced. As it was found that this emergency course lacked of interaction among teacher and students and students to students. These might contribute a negative effect to students' learning attainment. Third, learning after the aftershocks were not easy to maintain. The students, as well as the teacher, could not pay maximum attention to the lesson-related aspects. Thus, the condition likely brought a feeling of being unconfident and dissatisfied with the learning result. However, these three situational factors are still presuppositions based on this research finding and some related possibilities. Therefore, further research focusing on the factors underlying this condition is worth conducting to obtain a more relevant and accurate conclusion.

Although the students were not confident with the result of their learning process, most of them positively responded to this emergency course as the best alternative of the teaching-learning process within this disadvantaged condition. In response to the questionnaire and interview, they explicitly noted some advantages and disadvantages of the course such as flexibility and independent learning enhancement within the WhatsApp group. Overall, this study indicates that, in the emergency condition, the participants experienced advantages and disadvantages of asynchronous learning (Chauhan, 2017). Besides, the participants also voiced their preference for face-to-face learning approaches rather than the online ones. This belief might be shared since they experienced the asynchronous elearning for the first time.

This study has revealed how teaching and learning enactment after the earthquake and aftershocks situated in one public university in Lombok was geared by teacher and students. Data were found in four emerging themes such as teaching-learning approach, teaching materials, teacher and student interaction, and assessment process. Our findings essentialized that pedagogically-intended learning was not well-practiced in the four themes since the condition in the tents and refugees' camps where students temporarily lived are hindering to echo such teaching and learning activities (Dabner, 2012; Wodzicki, et.al, 2012; DeAndrea, et.al, 2012). Students in this context failed to experience a comfortable learning atmosphere (Shaw, et.al, 2004), and the teacher was also unable to facilitate active learning (Elgort, 2011). Although ready-used sources (e.g., textbooks) were exclusively used, pedagogically oriented learning was difficult to enact. The teacher could not share videos and other online teaching sources due to a lack of electricity (Arghode, et.al, 2018) since a particular electronic and internet-based technological tool would not work well when the electricity and the internet connection is insufficient (Savi, et.al, 2018).

In this emergency course, the teacher found that it was sophisticated to set effective interactions among students. After the aftershocks, teacher and students did not have enough time to interact. Teacher-student interaction had a significant influence on learning success, while studentstudent interaction did not give any impacts (Alghasab, et.al, 2019). Unfortunately, this study was not experimentally intended to investigate whether those interaction types significantly correlate with the students' attainment 
(Üzel \& Özdemir, 2012). The assessment process is another point to be considered in the teaching-learning process. The teacher has a wide range of chances to carry out various assessment instruments in the form of either formative or summative assessment (Nordström et al., 2019). Several ongoing assessments can also be carried out more easily in face-to-face instruction (Rawas et.al, 2019). This condition is quite different from what happened in the virtual classroom. The teacher found it difficult to carry out an ongoing assessment. Thus, the teacher selected a portfoliobased assessment in which the students had to carefully read the teacher's guidance to meet what each portfolio required them to do. In this process, students were required to do and glean each portfolio in their convenient time and place in which they were supposed to hand in those portfolios at particular decided time. Also, the teacher used the quiz and final test.

Responses to the interviews were also positive. Most of the students viewed the teaching and learning process helpful for them. This indicates that learning enthusiasm in such a disadvantaged condition is still held (van Harsel, et.al, 2019). Teacher in this study could successfully lead the students to sustained learning motivation regardless of several lacks in the process (Dunn \& Kennedy, 2019). Our study has documented that barriers encountered by teacher and students were mostly due to the uncontrolled disadvantaged condition. Although the teacher had remarkable endeavor to work effectively to engage the students in learning, the process was much hampered by a lack of facilities, such as electricity. Thus, online learning did not run effectively. Our findings also imply that policymakers and stakeholders should take a firm action in an open-school system for refugees.

\section{CONCLUSION}

This study has documented teaching-learning enactment of an EFL course under a disadvantaged condition in a classroom context of a public university based in Lombok, Indonesia. The findings have revealed that undertaking a specific course in a devastating earthquake and aftershocks is not a simple process. It needs rigorous consideration in terms of choosing the best model and how to deploy it effectively. In this case, this study has emphasized that asynchronous e-learning using WhatsApp was considered as the most applicable and accessible model for the teacher and students at the university in conducting the EFL course after the earthquake and aftershocks situation. Despite this, the instruction seems not entirely to reflect effective teaching.

The study also documents that benefits of a technological tool use were not sufficiently significant as promised. It might be due to some unavoidable factors, such as insufficient time for the teacher to design a more comprehensible instruction, lack of electricity and internet connection, and some psychological factors. In addition, the participating students in the study encountered multilayered obstacles in which they need more direct guidance from the teacher. Besides, they were not confident with their attainment in English skills and components. In response to the application of this course, the students positively reflected the course as the best way to learn in an extreme condition.

Further considerations on how to design materials and assessment instruments and build a decent interaction are needed in learning under such disadvantaged conditions. Research exploring EFL course implementation in disaster situations is also consistently underexplored. It is therefore an intriguing space for future researchers to investigate such an enactment from different angles of methodologies e.g., a large survey of quantitative data and perspectives e.g., teacher preparedness in learning and educational stakeholders' views on the course implementation.

\section{ACKNOWLEDGEMENTS}

We appreciate the anonymous reviewers for their feedback on the earlier version of this paper. We are also thankful to the research participants for their invaluable time during the project enactment.

\section{REFERENCES}

Amry, B. A. (2014). The impact of WhatsApp mobile social learning of the achievement and attitudes of female students and compared with face-to-face learning in the classroom. European Scientific Journal, 10(22), 116-136.

https://ejournal.org/index.php/esj/article/download/39 09/3700.

Alghasab, M., Hardman, J., \& Handley, Z. (2019). Teacherstudent interaction on wikis: Fostering collaborative learning and writing. Learning, Culture and Social Interaction, 21, 10-20. https://doi.org/10.1016/j.lcsi.2018.12.002

Arghode, V., Brieger, E., \& Wang, J. (2018). Engaging instructional design and instructor role in online learning environment. European Journal of Training and Development, 42(7/8), 366-380. https://doi.org/10.1108/EJTD-12-2017-0110

Arifani, Y. (2019). The application of small group and individual flipped model with WhatsApp to foster EFL learners' cohesive writing skill, Library Hi Tech News, 36(4), 10-12. https://doi.org/10.1108/LHTN12-2018-0075

Awada, G. (2016). Effect of WhatsApp on critique writing proficiency and perceptions toward learning. Cogent Education, 1-26.

https://www.tandfonline.com/doi/pdf/10.1080/23311 86X.2016.1

Bensalem, E. (2018). The impact of WhatsApp on EFL students' vocabulary learning. Arab World English Journal (AWEJ), 9(1), 23-38. DOI: https://dx.doi.org/10.24093/awej/vol9no1.2 
Chauhan, V. (2017). Synchronous and asynchronous learning. Imperial Journal of Interdisciplinary Research (IJIR), 3(2), 1345-1348. https://www.onlinejournal.in/IJIRV3I2/231.pdf

Chen, N. S., Ko, H. C., Kinshuk, \& Lin, T. (2005). A model for synchronous learning using the Internet. Innovations in Education and Teaching International, 42(2), 181-194.

Coldeway, D. (1995). Distance education revisited: an introduction to the Issue. In Simonson, M., S. Smaldino\& S. Zvacek (Eds.), Teaching and Learning at a Distance (pp. 7). New Jersey, NJ: Prentice-Hall, Inc.

DeAndrea, D. C., Ellison, N. B., LaRose, R., Steinfield, C., $\&$ Fiore, A. (2012). Serious social media: On the use of social media for improving students' adjustment to college. The Internet and Higher Education, 15(1), 15-23. https://doi.org/10.1016/j.iheduc.2011.05.009

Dabner, N. (2012). 'Breaking Ground' in the use of social media: A case study of a university earthquake response to inform educational design with Facebook. The Internet and Higher Education, 15(1), 69-78. https://doi.org/10.1016/j.iheduc.2011.06.001

Dunn, T. J., \& Kennedy, M. (2019). Technology enhanced Learning in higher education; motivations, engagement and academic achievement. Computers \& Education, 137, 104-113. https://doi.org/10.1016/j.compedu.2019.04.004.

Elgort, I. (2011). Dealing with complexity through course design. On the Horizon, 19(2), 97-108. https://doi.org/10.1108/10748121111138290

Giesbers, B., Rienties, B., Tempelaar, D., \& Gijselaers, W. (2014). A dynamic analysis of the interplay between asynchronous and synchronous communication in online learning: The impact of motivation. Journal of Computer Assisted Learning, 30(1), 30-50.

Hamad, M. M. (2017). Using WhatsApp to enhance students' learning of English language "experience to share". Higher Education Studies, 7(4), 74-87. http://doi.org/10.5539/hes.v7n4p74.

Hani, N. A. B. (2014). The impact of WhatsApp group's utilization of EFL students' vocabulary writing amelioration. International Journal of University Teaching and Faculty Development, 5(2), 73-87. http://s3.mazoneaws.com.

Huang, C.-Q., Han, Z.-M., Li, M.-X., Jong, M. S., \& Tsai, C.-C. (2019). Investigating students' interaction patterns and dynamic learning sentiments in online discussions. Computers \& Education, 140, 103589. https://doi.org/10.1016/j.compedu.2019.05.015

Johnson, G. M. (2006). Synchronous and asynchronous textbased CMC in educational contexts: A review of recent research. Tech Trends, 50(4), 46-53.

Man, C. (2014). Word's up with WhatsApp: the use of instant messaging in consciousness rising of academic vocabulary. 23rd MELTA and 12th Asia TEFL International Conference 28-30 August 2014, at Borneo Convention Centre, Kuching. Retrieved from

https://www.researchgate.net/publication/271854090
Maria, J. (2016). Use of WhatsApp to enhance reading and writing skills at undergraduate college level. Language in India, 16(11).

Retrieved from

http://www.languageinindia.com/nov2016/mariaWha tsApp final.pdf

Moore, M.G. (1989). Three types of interaction. The American Journal of Distance Education, 3(2), 1-6. http://aris.teluq.uquebec.ca/portals/598/t3_moore198 9.pdf

Mutch, C. (2015). Quiet heroes: teacher and Canterbury, New Zealand, earthquake. Australasian Journal of Disaster and Trauma Studies, 19(2), 77-86.

http://trauma.massey.ac.nz/issues/20152/AJDTS 19_2_Mutch.pdf.

Neroni, J., Meijs, C., Gijselaers, H. J. M., Kirschner, P. A., \& de Groot, R. H. M. (2019). Learning strategies and academic performance in distance education. Learning and Individual Differences, 73, 1-7. https://doi.org/10.1016/j.lindif.2019.04.007.

Nordström, T., Andersson, U. B., Fälth, L., \& Gustafson, S. (2019). Teacher inquiry of using assessments and recommendations in teaching early reading. Studies in Educational Evaluation, 63, 9-16. https://doi.org/10.1016/j.stueduc.2019.06.006

Rawas, H., Bano, N., \& Alaidarous, S. (2019). Comparing the effects of individual versus group face-to-face class activities in flipped classroom on student's test performances. Health Professions Education, S2452301119300033.

https://doi.org/10.1016/j.hpe.2019.06.002

Offir, B., Lev, Y., \& Bezalel, R. (2008). Surface and deep learning processes in distance education: Synchronous versus asynchronous systems. Computers \& Education, 51(3), 1172-1183.

Pietro, G.D. (2015). The academic impact of natural disaster: evidence from L'Aquila Earthquake. IZA Discussion Paper No 8867, London, UK.

Redmond, P. (2011). From face-to-face teaching to online teaching: pedagogical transitions. Proceedings ASCILITE 24 - 7 December 2011 Hobart: Full Paper. 1050-1060, at Hobart Tasmania Australia. Retrieved from

http://www.ascilite.org/conferences/hobart11/downlo ads/papers/Redmond-full.pdf.

Savi, A. O., Ruijs, N. M., Maris, G. K. J., \& van der Maas, H. L. J. (2018). Delaying access to a problemskipping option increases effortful practice: Application of an A/B test in large-scale online learning. Computers \& Education, 119, 84-94. https://doi.org/10.1016/j.compedu.2017.12.008

Shaw, R., Shiwaku Hirohide Kobayashi, K., \& Kobayashi, M. (2004). Linking experience, education, perception and earthquake preparedness. Disaster Prevention and Management: An International Journal, 13(1), 39-49. https://doi.org/10.1108/09653560410521689

Seyle, C., Widyatmoko, S., \& Silver, R.C. (2013). Coping with natural disasters in Yogyakarta, Indonesia: A study of elementary school teachers. School Psychology International, 34(4) 387-404. 
DOI: $10.1177 / 0143034312446889$.

https://pdfs.semanticscholar.org/906a/3906cdf718dc8 c0af6d239ab4664cc817285.pdf.

Song, L., Watulak, S. L., Kritskaya, O., \& Elmendorf, D. (2013). Exploring undergraduate students' skills, level of comfort, and perceived benefit of using technology for learning. International Journal of Technology in Teaching and Learning, 9(1), 18-36.

Üzel, D., \& Özdemir, E. (2012). The effects of problembased e-Learning on prospective teachers' achievements and attitudes towards learning mathematics. Procedia - Social and Behavioral Sciences, 55, 1154-1158.

https://doi.org/10.1016/j.sbspro.2012.09.609

Van Harsel, M., Hoogerheide, V., Verkoeijen, P., \& van Gog, T. (2019). Effects of different sequences of examples and problems on motivation and learning. Contemporary Educational Psychology, 58, 260275. https://doi.org/10.1016/j.cedpsych.2019.03.005

Wodzicki, K., Schwämmlein, E., \& Moskaliuk, J. (2012). "Actually, I Wanted to Learn": Study-related knowledge exchange on social networking sites. The Internet and Higher Education, 15(1), 9-14. https://doi.org/10.1016/j.iheduc.2011.05.008

Zulkanain, N. A., Miskon, S., \& Abdullah, N. S. (2020). An adapted pedagogical framework in utilizing WhatsApp for learning purpose. Education and Information Technologies, 1-12.

Conflict of Interest Statement: The authors declare that the research was conducted in the absence of any commercial or financial relationships that could be construed as a potential conflict of interest.

Copyright (C) 2021 Khusnul Khotimah, Kurniawan Apgrianto, Mutmainnah Mustofa, M. Faruq Ubaidillah, E Shinta Amalia. This is an open-access article distributed under the terms of the Creative Commons Attribution License (CC $B Y)$. The use, distribution or reproduction in other forums is permitted, provided the original author(s) and the copyright owner(s) are credited and that the original publication in this journal is cited, in accordance with accepted academic prac- tice. No use, distribution or reproduction is permitted which does not comply with these terms. 